\title{
Seeking practical advice
}

Nancy A. McLeod, MD, Fairhope, AL: For 30 years, I have been honing my skills as a physician. The Cartesian approach to disease management is essentially evidence-based medical practice, but I am finding it increasingly difficult to follow. Frankly, I need some practical advice.

A patient whose seizures were controlled with 3 drugs recently asked to switch to generics because the co-pays for his antiepileptic drugs (AEDs) were running $\$ 1,200$ per month. I agreed but requested AED levels after 4 weeks on the generics. The levels were all mid-therapeutic and he was seizure-free, so we continued. Four weeks later, I received a call from his wife reporting confusion, slurred speech, and partial complex events. When I examined him that day, he looked "toxic." The only change was that he had had his prescriptions refilled 2 weeks prior (same pharmacy) and that the pills looked different. His AED levels were markedly changed: drug no. 1, subtherapeutic; drug no. 2, level reduced to low therapeutic; drug no. 3, toxic. He resumed branded drugs and was back to baseline in a week. There was not a compliance problem; I had asked his wife to dispense his medications some months prior, and she was doing so.

I know how important consistency of medication delivery is for seizure control, but how do I provide that when third-party payers demand failure on generics first and continue to charge a premium or even impose a penalty? The "step-program" requires failure on a patient-bypatient basis rather than optimizing success by relying on the skills of a knowledgeable and experienced physician. I wonder why no one has actually done a study of quality to assess the "step" program using not only financial but also quality-of-life measures.

Help us apply the knowledge gained to the circumstances we face for the sake of our profession and our patients.

Disclosures: The author reports no disclosures.

Correspondence to: mdnancy@bellsouth.net

Editors Respond: Your comments clearly illustrate the rampant frustration with the state of affairs in clinical practice. We hope that this issue of Neurology: Clinical Practice begins to address your concerns. We invite our readers to share their thoughts.

\section{Bell's palsy treatment strategies: Antivirals may help some patients}

Richard B. Tenser, MD, Penn State University College of Medicine, Hershey, PA: The suggested use of antivirals ${ }^{1}$ in the treatment of Bell's palsy is probably not supported by basic science or clinical science data. Herpes simplex virus (HSV) latent infection of trigeminal ganglion neurons as the substrate of recurrent oral-facial HSV infection has been well-established. During the period of HSV latency, viral RNA transcripts have been demonstrated in ganglion neurons by in situ hybridization. With viral reactivation, viral antigens and infectious virus are readily detected in ganglia. However, evidence of neuronal latency or of viral reactivation is not available for the geniculate ganglion in patients with Bell's palsy. From the clinical vantage point, the large study of Sullivan et al., ${ }^{2}$ which showed efficacy of steroid alone and no antiviral benefit, is compelling. In addition, the fact that steroid alone did not worsen putative viral infection suggests that viral infection is probably not present. The emphasis on antiviral use while likely not clinically harmful has probably slowed investigations of the true cause of Bell's palsy. Evidence-based medicine does not support the use of antivirals in the treatment of Bell's palsy.

Disclosures: R. Tenser has received honoraria from Biogen Idec, Novartis, Pfizer/Serono, and Teva.

Correspondence to: rtenser@psu.edu 
Author Responds: John J. Halperin, MD, Overlook Medical Center, Summit, NJ: I thank Dr. Tenser for his comments, with which I largely agree. The point of the article was simply that the available studies do not exclude the possibility of a small incremental benefit of antivirals when added to corticosteroids. To resolve this issue definitively would require a large study in which patients were treated with corticosteroids plus either antivirals or placebo, were stratified by initial severity of the Bell's palsy, were assessed for HSV1 vs varicella-zoster virus, and outcomes were assessed quantitatively. Whether or not it would be worthwhile to perform such a study to identify a potential incremental benefit of a few percentage points can be legitimately debated, but might be viewed positively by individuals with persistent facial paralysis who had received corticosteroid treatment alone.

Disclosures: See original article for full disclosure list.

Correspondence to: halperin@lineuro.com.

1. Halperin JJ. Bell's palsy treatment strategies: antivirals may help some patients. Neurol Clin Pract 2012;2:245-247.

2. Sullivan FM, Swan IRC, Donnan PT, et al. Early treatment with prednisone or acyclovir in Bell's palsy. N Engl J Med 2007;357:1598-1607.

\section{Do You Know What is Happening to Neurology on} Capitol Hill?

Congress is making decisions that affect neurologic research funding and the way neurology is practiced in the United States. Only Capitol Hill Report on AAN.com takes you behind Washington's closed doors and shines a light on how your federal legislators are working for-or against-your interests. Read Capitol Hill Report on AAN.com the second and fourth Wednesday of each month. Stay informed. Your work depends on it. 


\title{
Neurology ${ }^{\circ}$ Clinical Practice
}

\author{
Seeking practical advice \\ Nancy A. McLeod, Richard B. Tenser and John J. Halperin \\ Neurol Clin Pract 2013;3;2-3 \\ DOI 10.1212/CPJ.0b013e31828385bc
}

This information is current as of February 18, 2013

\begin{tabular}{|c|c|}
\hline $\begin{array}{l}\text { Updated Information \& } \\
\text { Services }\end{array}$ & $\begin{array}{l}\text { including high resolution figures, can be found at: } \\
\text { http://cp.neurology.org/content/3/1/2.full.html }\end{array}$ \\
\hline References & $\begin{array}{l}\text { This article cites } 2 \text { articles, } 1 \text { of which you can access for free at: } \\
\text { http://cp.neurology.org/content/3/1/2.full.html\#\#ref-list-1 }\end{array}$ \\
\hline Permissions \& Licensing & $\begin{array}{l}\text { Information about reproducing this article in parts (figures,tables) or in } \\
\text { its entirety can be found online at: } \\
\text { http://cp.neurology.org/misc/about.xhtml\#permissions }\end{array}$ \\
\hline Reprints & $\begin{array}{l}\text { Information about ordering reprints can be found online: } \\
\text { http://cp.neurology.org/misc/addir.xhtml\#reprintsus }\end{array}$ \\
\hline
\end{tabular}

Neurol Clin Pract is an official journal of the American Academy of Neurology. Published continuously since 2011, it is now a bimonthly with 6 issues per year. Copyright () 2013 American Academy of Neurology. All rights reserved. Print ISSN: 2163-0402. Online ISSN: 2163-0933.

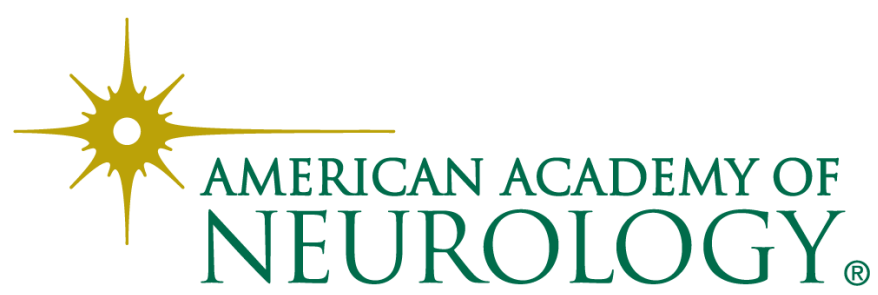

